\title{
Horizontal gene transfer between Wolbachia and the mosquito Aedes aegypti
} Lisa Klasson, Zakaria Kambris, Peter E Cook, Thomas Walker and Steven P Sinkins*

Address: Department of Zoology, University of Oxford, South Parks Road, Oxford, OX1 3PS, UK

Email: Lisa Klasson - lisa@garborg.se; Zakaria Kambris - zakaria.kambris@zoo.ox.ac.uk; Peter E Cook - peter.cook@zoo.ox.ac.uk; Thomas Walker - thomas_walker79@hotmail.com; Steven P Sinkins* - steven.sinkins@zoo.ox.ac.uk

* Corresponding author

Published: 20 January 2009

BMC Genomics 2009, 10:33
Received: 22 December 2008

Accepted: 20 January 2009

(C) 2009 Klasson et al; licensee BioMed Central Ltd.

This is an Open Access article distributed under the terms of the Creative Commons Attribution License (http://creativecommons.org/licenses/by/2.0), which permits unrestricted use, distribution, and reproduction in any medium, provided the original work is properly cited.

\begin{abstract}
Background: The evolutionary importance of horizontal gene transfer (HGT) from Wolbachia endosymbiotic bacteria to their eukaryotic hosts is a topic of considerable interest and debate. Recent transfers of genome fragments from Wolbachia into insect chromosomes have been reported, but it has been argued that these fragments may be on an evolutionary trajectory to degradation and loss.

Results: We have discovered a case of HGT, involving two adjacent genes, between the genomes of Wolbachia and the currently Wolbachia-uninfected mosquito Aedes aegypti, an important human disease vector. The lower level of sequence identity between Wolbachia and insect, the transcription of all the genes involved, and the fact that we have identified homologs of the two genes in another Aedes species (Ae. mascarensis), suggest that these genes are being expressed after an extended evolutionary period since horizontal transfer, and therefore that the transfer has functional significance. The association of these genes with Wolbachia prophage regions also provides a mechanism for the transfer.
\end{abstract}

Conclusion: The data support the argument that HGT between Wolbachia endosymbiotic bacteria and their hosts has produced evolutionary innovation.

\section{Background}

Wolbachia pipientis is an intracellular inherited bacterium found in arthropods, where it manipulates host reproduction using phenotypes such as cytoplasmic incompatibility (CI), male killing, parthenogenesis and feminization, and can spread rapidly through insect populations [1]. It is also an obligate mutualist of a number of filarial nematode species [2].

Several cases where sections of the Wolbachia genome, sometimes large, have been transferred to the host chro- mosomes are now known in both insects and nematodes [3-5]. These are either recent events where Wolbachia and host sequences are highly similar or involve extensive pseudogenization [4]. Transcription was reported for $2 \%$ of the genes transferred to Drosophila ananassae but the levels were estimated to be $10^{4}$ to $10^{7}$ fold lower than for a control gene, act5C $[5,6]$, and it has been argued that this could represent background transcriptional noise (as occurs for many pseudogenes) rather than functional expression $[7,8]$ - translation has yet to be demonstrated. It has therefore been suggested that these fragments are on 
an evolutionary trajectory to degradation by neutral mutation and play no significant part in host evolution [8]. If so they would be analogous to the non-functional nuclear fragments of mitochondrial DNA present in some animal genomes [9], which are transient and in the process of decay.

The case has therefore been made that if Wolbachia-insect HGT has evolutionary significance, both longevity and integration into host biology would need to be demonstrated [8]; and furthermore that we would expect to see Wolbachia-like genes in species that do not currently harbour Wolbachia but presumably did in the past. Both phylogenetic analyses and theory suggest that Wolbachia can be lost over time from host species by a variety of mechanisms [10-12]. Aedes aegypti, the most important mosquito vector of human dengue fever and various other arboviruses, is naturally Wolbachia-uninfected but has been shown to be able to support Wolbachia following artificial transinfection - with both high rates of maternal inheritance and the expression of high levels of CI [13]. The examination of its sequenced genome [14] for any genes that could have originated in Wolbachia was therefore undertaken.

\section{Results and discussion}

We have discovered a case of HGT involving adjacent genes in the genomes of Ae. aegypti and two Wolbachia strains. The Ae. aegypti gene AAEL004181 shares around $50 \%$ amino acid identity with two genes in the genome of Wolbachia strain $w$ Pip [15] from the mosquito Culex quinquefasciatus, WP1348 and WP1346), which were probably originally a single gene split by insertion of IS element WP1347, and also with WD0513 in strain $w$ Mel from Drosophila melanogaster [16]. The adjacent Ae. aegypti gene AAEL004188 shows partial similarity to $w$ Pip WP1349 and to $w \mathrm{Mel}$ WD0514 and is inverted compared to the
Wolbachia genes. The intergenic region between AAEL004181 and AAEL004188 is around $15 \mathrm{~Kb}$ (Figure 1 ). The level of sequence identity and the fact that adjacent sets of genes are involved provide a robust case for an HGT event.

RT-PCR analysis was conducted and confirmed that $A e$. aegypti genes AAEL004181 and AAEL004188 were transcribed in both male and female adult mosquitoes. The Wolbachia $w$ Pip genes WP1348 and WP1346 were clearly amplified by RT-PCR in adult $C x$. quinquefasciatus of both sexes, indicating that they are also transcribed. Primers AAEL004181 b, c and i were designed to span three introns present in the Aedes aegypti Vectorbase annotation for AAEL004181; based on product size from RT-PCR amplification (Figure 2 and Table 1), all of these three introns proved to be mis-annotations and it was concluded that no introns are present. The apparent absence of introns, which would be particularly unusual for a mosquito gene of the size of AAEL004181, is suggestive of a bacterial origin.

Full genome microarrays for Aedes aegypti were hybridized to cDNA from adult females, as shown in Figure 3. All probes with hybridization signal levels significantly above background (see methods) were ranked in order of signal intensity; $4.9 \%$ of these probes (or approximately $15 \%$ of all probes) showed lower signal intensity than was seen for either of the two AAEL004181 probes, while $28.2 \%$ of probes significantly above background $(42 \%$ of all probes) showed lower signal intensity than was seen for either of the two AAEL004188 probes. Quantitative RTPCR data for AAEL004188, AAEL004188 and he act5C gene used as a control by Hotopp et al. [5] matched the array results, as shown in figure 3 . The act $5 \mathrm{C}$ gene is, as the authors note, highly and constitutively expressed and may in fact be an overly stringent point of comparison to assess

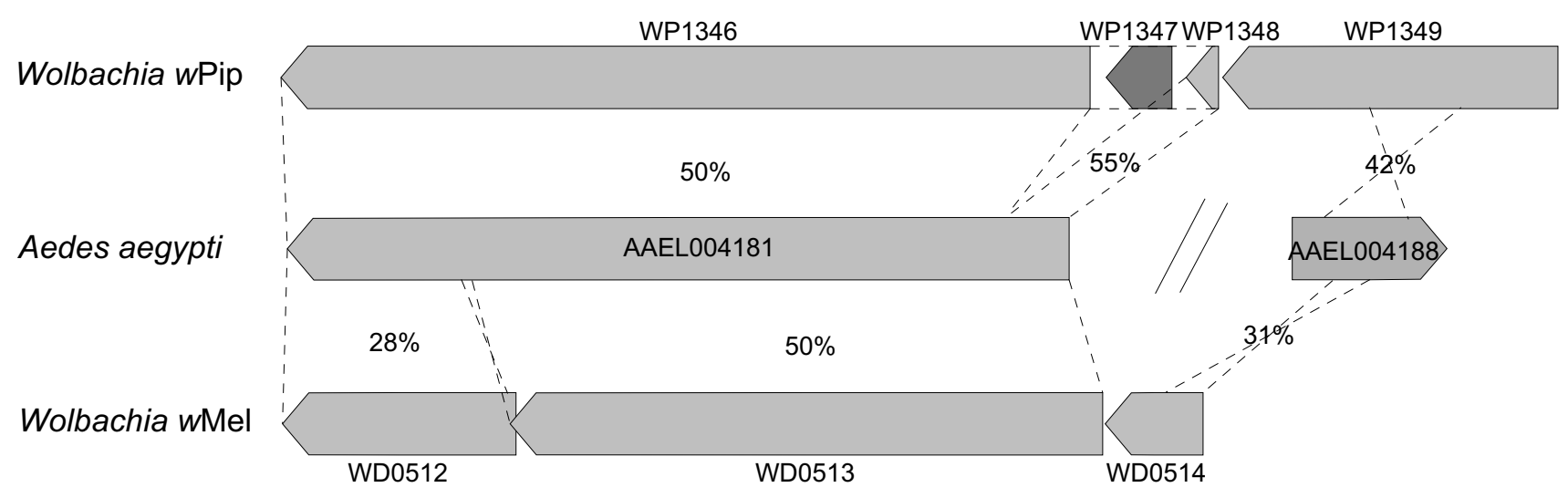

Figure I

A. Percent amino acid identities shared between Aedes aegypti and Wolbachia genes/gene regions. 


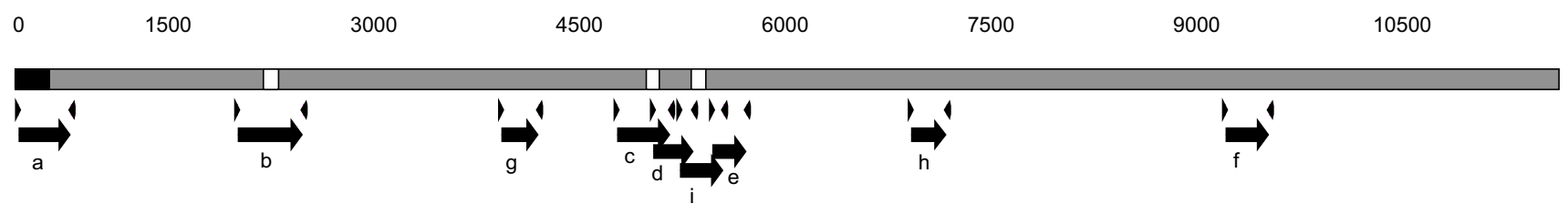

\begin{abstract}
Figure 2
Map showing positions of oligonucleotide PCR primers for gene AAEL004 I 8 I and the positions of introns (white boxes) present in the Aedes aegypti Vectorbase annotation for this gene (see Table I for primer sequences, product sizes and conditions used in the study). The black box represents an extension of the gene compared to the annotation in Vectorbase. Primers AAEL004I8I b, $\mathrm{c}$ and i were designed to span these introns produced RT-PCR products identical in size to those produced by genomic PCR, confirming that the introns were in fact mis-annotations; RTPCR using AAEL004 I8la extended the 5' end of the exon.
\end{abstract}

whether horizontally transferred genes are likely to be functional. In the microarray data a number of genes of known function showed very similar or lower hybridization intensities relative to the two genes of interest; for example the probes for AAEL012836 (Cytochrome B561) and AAEL002230 (encoding a chromatin helicase DNA binding protein) showed very similar hybridization intensities as AAEL004181, while AAEL013002 (Cdk9) and AAEL010226 (Daughterless) showed very similar hybridization levels as AAEL004188. Based on these data it is considered likely that both AAEL004181 and AAEL004188 are expressed, functional genes, although obviously definitive proof of this will require the raising of antibodies followed by protein studies.

Close homologs of the two Ae. aegypti genes could not be found in other sequenced mosquito/insect genomes such as Anopheles gambiae [17]. Various PCR primer pairs designed for the Aedes aegypti genes AAEL004181 and AAEL004188 failed to amplify PCR products from several other fellow subgenus Stegomyia members, but did amplify products for both genes from Ae. mascarensis (Table 2). This species, from Mauritius, is able to produce sterile offspring in laboratory crosses with Ae. aegypti [18]. Ae. mascarensis PCR products from AAEL004181 primers b \& f plus $g$ \& h (see Figure 2 and Table 1), located in diverse regions of the gene, were sequenced and shared a mean 97\% nucleotide identity over 1278 base pairs with Ae. aegypti AAEL004181. Diverged homologs of the two genes may well be present in other more distant Aedes species, but could not be detected here. Thus, if the direction of the HGT was from Wolbachia to host it would have occurred at least prior to the species divergence of Ae. aegypti and Ae. mascarensis and indeed the accumulation of the $15 \mathrm{~Kb}$ of non-coding DNA between the two genes would likely have required a considerable period of time (although it is not possible to make any precise time estimates from the data available).

The $w$ Pip genes are located at the end of a genomic prophage region, providing a putative mechanism for the
HGT. Wolbachia have been shown to contain phage particles by EM in several studies; WO prophage have been shown to be highly variable and rapidly evolving regions in the genomes of mosquito Wolbachia, and non-congruent with host phylogeny [19-24], strongly suggesting that lateral transfer of phage between Wolbachia strains has occurred. The two $w$ Mel genes WD0512 and WD0513 are part of an operon that also contains the ankyrin repeat domain (ANK) encoding gene WD0514. This operon is present in mod+strain variants of $w \mathrm{Mel}$ (able to induce CI in males) but not in the related mod-strain $w$ Au (unable to induce CI) [25]. The operon is located in a region of the $w \mathrm{Mel}$ genome that was shown to be missing in $w \mathrm{Au}$, WD0506-WD0518 in $w \mathrm{Mel}$, and in fact all these genes have homologs in the prophage regions of the $w$ Pip genome, except for the ANK gene WD0514. Therefore, although not annotated as prophage [16], these genes in $w \mathrm{Mel}$ are likely to be remnants of an old prophage region, the rest of which has been deleted or rearranged.

The Ae. aegypti gene AAEL004181 also shares considerably lower amino acid similarity with a group of genes in the Ae. aegypti, Anopheles gambiae and Culex pipiens genomes. One of these Ae. aegypti genes showed female salivary gland specific expression and was named aaSGS1 (SGS = Salivary Gland Specific). This gene and homologs in Anopheles are candidate Plasmodium sporozoite receptors $[26,27]$. It has already been suggested that the SGS-type mosquito genes might have arisen from an ancient transfer between Wolbachia and mosquitoes, but with weak support $[26,27]$.

An alternative hypothesis is that the direction of horizontal transfer was in fact from Aedes into Wolbachia, and AAEL004181 is part of a family of SGS-type genes that originated and evolved in mosquitoes. The acquisition of host genes by Wolbachia has not previously been documented. It could be argued that this scenario is more parsimonious since only one inter-domain HGT event would be required, if a subsequent transfer from $w$ Pip (or a related strain) to $w \mathrm{Mel}$ is assumed. In contrast, the 
Table I: Sequences $\left(5^{\prime}-3^{\prime}\right)$, optimal annealing temperatures $\left({ }^{\circ} \mathrm{C}\right)$ and amplified fragment sizes (base pairs) for primers used in the study.

\begin{tabular}{|c|c|c|c|}
\hline & primer sequence & $\begin{array}{l}\text { product } \\
\text { size (bp) }\end{array}$ & optimal annealing temperature $\left({ }^{\circ} \mathrm{C}\right)$ \\
\hline WPI346a* & $\begin{array}{l}\text { F-TGGTTGGTCACTACCACGAA } \\
\text { R-ACCATTCGGCACTGAAACAT }\end{array}$ & 432 & 54 \\
\hline WPI346b & $\begin{array}{l}\text { F-TGAGCATGGTCGTTTATTGG } \\
\text { R-CGCACATCTTTCATCCAGAG }\end{array}$ & 453 & 54 \\
\hline WPI346c & $\begin{array}{l}\text { F-TCAATCTCGCAAGTTGATGC } \\
\text { R-AAATGACCTTGAACGGAAGC }\end{array}$ & 529 & 54 \\
\hline WPI348* & $\begin{array}{l}\text { F-ACGACAAGCCTTTTCCTTTG } \\
\text { R-TAATATTGCCGGGCTTGTTC }\end{array}$ & 355 & 54 \\
\hline WPI349a* & $\begin{array}{l}\text { F-TGGATGTGCGACGTTCTAAG } \\
\text { R-TCGGCTGGTAATCCTTTTTG }\end{array}$ & 399 & 54 \\
\hline WPI349b & $\begin{array}{l}\text { F-GTGGAATTTTGAAGGCCAAG } \\
\text { R-AGGCCCAACATTTTCTTGTG }\end{array}$ & 372 & 54 \\
\hline AAEL004I8Ia* & $\begin{array}{l}\text { F-TTCTCCGACCAGATTTTTCC } \\
\text { R-AGAAATGTCCCGCCCTTATC }\end{array}$ & 370 & 54 \\
\hline AAEL004I8Ib*A $\dagger$ & $\begin{array}{l}\text { F-GAACAAGGGGATCAAGCAAA } \\
\text { R-CTTGAATGACCCGAGTGAGA }\end{array}$ & 475 & 54 \\
\hline AAEL004I8I $c^{* \Lambda}$ & $\begin{array}{l}\text { F-CGGAACTCTGGTGGGTACAT } \\
\text { R-AGACGTTCGCTTGAAAATCG }\end{array}$ & 388 & 55 \\
\hline AAEL004I8Id & $\begin{array}{l}\text { F-catcggttattgaaccggatac } \\
\text { R-caacttcactattctgccaacg }\end{array}$ & 296 & 54 \\
\hline AAEL004I8Ie & $\begin{array}{l}\text { F-tcttccgataggttacggattg } \\
\text { R-tcgatgtataagcctccatcaac }\end{array}$ & 251 & 54 \\
\hline AAEL004I8If*t & $\begin{array}{l}\text { F-ACAACCAGTGGAATCCTTCG } \\
\text { R-GTTCTCATTTGCGACCCAAT }\end{array}$ & 318 & 55 \\
\hline AAEL004I8Ig ${ }^{\dagger}$ & $\begin{array}{l}\text { F-cgctgaaactgtacagacaagg } \\
\text { R-tttcattcgtgttgaagtggtc }\end{array}$ & 273 & 54 \\
\hline AAEL004I8I $\mathrm{h}^{\dagger}$ & $\begin{array}{l}\text { F-acaccactttcgattgtcattg } \\
\text { R-ggcccttcatagctgtagtgac }\end{array}$ & 260 & 54 \\
\hline AAEL004I8Ii*^ & $\begin{array}{l}\text { F-GCCATCATCAGGAACCAATC } \\
\text { R-CTGATTGCAGCGAGAAATGA }\end{array}$ & 317 & 55 \\
\hline AAEL004I88*† & $\begin{array}{l}\text { F-TGGACACAAAGACCCATTCA } \\
\text { R-AAAACTGGGTGCTTCCATTG }\end{array}$ & 447 & 53 \\
\hline
\end{tabular}

\footnotetext{
*denotes primers used for RT-PCR to determine gene expression. ^denotes primers designed to span three introns present in the Aedes aegypti Vectorbase annotation for AAELO04I8I. †denotes primers used for sequencing Aedes mascarensis PCR products.
}

hypothesis of Wolbachia to Aedes transfer requires a different origin of the SGS genes compared to AAEL004181. However, phylogenetic reconstruction (Figure 4) does not support the hypothesis of a single host-to-Wolbachia HGT, since AAEL004181 clusters with the $w$ Pip gene WP1346 with a posterior probability of 1 and a boostrap value of 89. If AAEL004181 had been transferred from mosquito to Wolbachia followed by subsequent transfer between Wolbachia strains, the $w$ Pip and $w$ Mel sequences would be expected to be more closely related to each other than to 

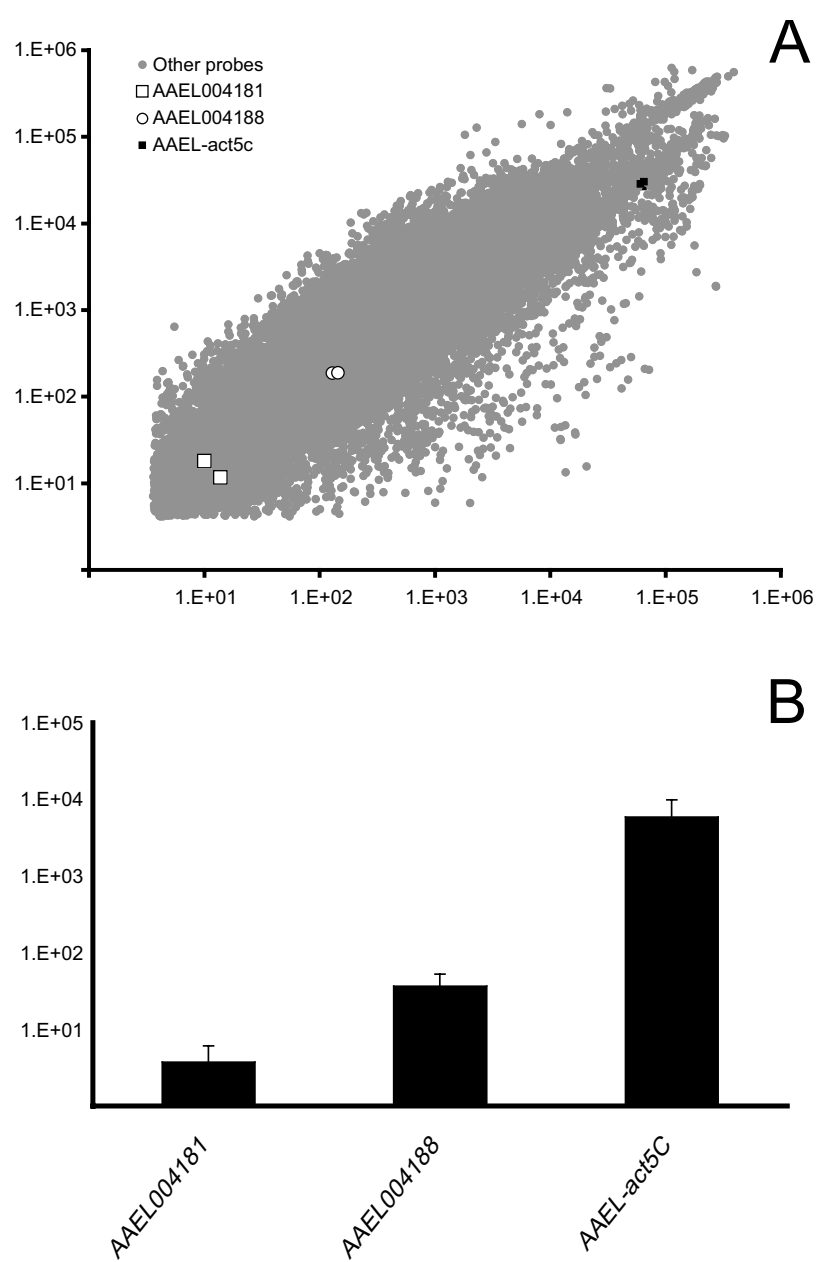

Figure 3

A. Transcript levels of Ae. aegypti genes, AAEL004I 8 I and AAEL004 I 88, relative to whole genome transcription. Microarrays incorporating two distinct 60-mer probes for each annotated Ae. aegypti gene were used to investigate transcript abundance in pools of adult female mosquitoes. In the example shown, array I was hybridised with cRNA from young mosquitoes ( $0-2$ days post-eclosion) and Array 2 with cRNA from older mosquitoes ( I 4-16 days post-eclosion). Log cyanine-3 signal intensity is shown for all probes $(n=29840)$ significantly above background fluorescence (see methods). B. AAEL004I8I, AAEL004I 88 and act5C genes expression in Aedes aegypti females as monitored by quantitative RT-PCR. The values shown are the average of three different assays on independent samples. Error bars indicate standard error.

AAEL004181 and thus cluster together in the phylogenetic tree, which is not the case. Thus, both phylogenetic evidence and the lack of introns support a Wolbachia-to-host direction of transfer of AAEL004181. The SGS genes may also have had a bacterial origin, as suggested by their apparent lack of introns, but if this is the case then the
HGT event or events responsible would be separate from that involving AAEL004181 (and probably pre-date it, given their greater distance from the Wolbachia genes).

\section{Conclusion}

The data presented provide a robust case for HGT between Wolbachia and mosquitoes, and we consider Wolbachia-tohost to be the most likely direction of this transfer of the genes AAEL004181/8 in Ae. aegypti and mascarensis. Our results support the argument that HGT between Wolbachia and their insect hosts has led to the acquisition of evolutionary innovation, provide a putative mechanism for transfer via nuclear-phage recombination, and suggest that the previously documented examples of recent/ongoing Wolbachia-host HGT may have considerably more significance than interesting, but transient, phenomena.

\section{Methods}

Mosquito DNA and RNA extraction, PCR, sequencing, and RT-PCR using a Qiagen one-step RT-PCR kit were carried out as previously described $[22,28]$. DNA from Museum specimens was extracted using a Qiagen QIAamp DNA micro kit according to the manufacturers instructions. Primers were designed using Primer3 [29] and previously published primers for gene $w s p(81 \mathrm{~F}$ and 691R)[30] were used to check for presence of Wolbachia, and AegS7F and R primers amplifying the ribosomal S7 gene [31] as controls for Aedes DNA quality. DNA from Aedes simpsoni, heischi, soleatus, calceatus, metallicus and mascarensis (all considered phylogenetically close to Ae. aegypti) was extracted from preserved Museum specimens; only data from specimens where strong AegS7 amplification was observed were included. DNA from Ae. aegypti and $A e$. albopictus was extracted from laboratory specimens.

\section{Quantitative RT-PCR}

Gene expression levels were monitored using quantitative RT-PCR (qRT-PCR). Total RNA was extracted with TRIzol ${ }^{\mathrm{TM}}$ reagent from groups of ten Aedes aegypti females and cDNA was synthesized from 1 microgram of total RNA using SuperScript II enzyme (Invitrogen) following the manufacturer's protocol. qRT-PCR was performed on a 1 in 20 dilution of the cDNAs using dsDNA dye SYBR Green I. Reactions were run on a DNA Engine thermocycler (MJ Research) with Chromo4 real-time PCR detection system (Bio-Rad) using the following cycling conditions: 95C for 15 minutes, then 45 cycles of $95 \mathrm{C}$ for $10 \mathrm{~s}$, 59C for $10 \mathrm{~s}$, $72 \mathrm{C}$ for 20s, with fluorescence acquisition at the end of each cycle, then a melting curve analysis after the final one. The cycle threshold $(\mathrm{Ct})$ values were determined and background fluorescence was subtracted. Gene expression levels of target genes were calculated, relative to the internal reference gene RpS17 (ribosomal protein S17). Primer pairs used to detect target gene transcripts were as follows: 
Table 2: PCR amplification results from genomic DNA to examine the distribution of Ae. aegypti genes AAEL004I8I and AAEL004I88, plus presence/absence of Wolbachia, among other species in the Aedes subgenus Stegomyia.

\begin{tabular}{ccccc}
\hline & aegypti & albopictus & simpsoni, heischi, calceatus, metallicus, soleatus & mascarensis \\
\hline wsp - Wolbachia & - & + & - & + \\
Aeg S7 - control & + & + & - & - \\
AAEL00418Ia & + & - & - & + \\
AAEL00418Ib & + & - & - & + \\
AAEL00418Ic & + & - & - & - \\
AAEL00418d & + & - & - & - \\
AAEL00418Ie & + & - & - \\
AAEL00418If & + & - & + \\
AAEL004188 & + & - & + \\
\hline
\end{tabular}

+ indicates a clear PCR product of the correct size.

AAEL004181 (forward: 5'-GTT TCC GCA GAA GAA TCA GC-3', reverse: 5'-AGT TCG TCT CCA AAG CAG GA-3'); AAEL004188 (forward: 5'-TGA ATT GCT GCT ACG GTT TG-3', reverse: 5'-TGA ATG GGT CTT TGT GTC CA-3'); Actin5C (forward: 5'-ATC GTA CGA ACT TCC CGA TG-3', reverse: 5'-ACA GAT CCT TTC GGA TGT CG-3') and control RpS17 (forward: 5'-CAG GTC CGT GGT ATC TCC AT3', reverse: 5'-CAG GAC ATC ATC GAA GTC GA-3').

\section{Microarray experiments}

Custom Ae. aegypti microarrays were designed using Agilent eArray software [32]. A probe set, containing two unique 60-mers per annotated Ae. aegypti gene, was designed using the gene expression probe design module. These probes were randomly position across the surface of the array.

Aedes aegypti were reared using standard procedures to either 0-2 days (young) or 14-16 days (old) posteclosion before collection. Total RNA was extracted from pools of 10 female Ae. aegypti using Trizol reagent (Invitrogen) and following the manufacturer's protocol. Isolated total RNA was quantified on the Nanodrop ND1000 spectrophotometer. The two-colour low RNA input linear amplification kit PLUS kit (Agilent Technologies) was used to amplify cyanine-3 (Cy3) and cyanine-5 (Cy5) labeled complimentary RNA (cRNA) from $1.5 \mu \mathrm{g}$ of total RNA from each pool of female mosquitoes. cRNA samples were purified using RNeasy mini kits (Qiagen), then cRNA concentration and dye incorporation (labeling efficiency) where quantified using the Nanodrop. Prepared cRNA samples were hybridized to four $4 \times 44 \mathrm{~K}$ format microarrays using Agilent reagents and protocols. Microarray slides were washed following Agilent protocols to prevent ozone degradation and scanned with an Agilent scanner at $5 \mu \mathrm{m}$ scan resolution using the extended dynamic range (XDR) function (XDR Hi 100\%, XDR Lo $10 \%$ ). Agilent feature extraction software (version 9.5.3) was run on all array datasets using the GE2-v5_95_Feb07 protocol. This protocol reports processed Cy3 and Cy5 signal intensities and identifies probes significantly expressed above background (2-sided t-test; $\mathrm{P}=0.01$ ).

\section{Phylogenetic analysis}

The two genes WP1346 and WP1348 in Wolbachia strain $w$ Pip and the two genes WD0512 and WD0513 from Wolbachia strain $w$ Mel were concatenated. The gene AAEL004181 from Aedes aegypti was extended to the new start codon and the parts annotated as introns were included. All genes identified as putative SGS family members by searching the genomes of Anopheles gambiae, Aedes aegypti and Culex quinquefasciatus with tblastn in VectorBase [33] were extracted. All gene sequences were, if necessary, extended to the putatively correct start codon based on homology with AAEL004181 and introns were included and translated together with the exon sequences. The gene annotated as CPIJ007816 contained two large open reading frames that were both similar to the SGS genes, they were both included and are called CPIJ007816a and b. Two SGS genes from Anopheles gambiae, agSGS2 and agSGS3 sequenced by Korochkina et al. [27], were retrieved separately from Genbank, since the corresponding region in the Anopheles gambiae genome contains sequence gaps. The amino acid sequences were aligned using MUSCLE [34]. Phylogenetic reconstruction was performed using MrBayes 3.12 [35], with the mixed amino acid model. The program was run for 200,000 generations, sampling every $100^{\text {th }}$ generation, using 2 runs with 4 chains in each. A consensus tree was constructed using a burnin of $25 \%$ of the sampled trees. A maximum likelihood analysis was conducted using RAxML ver. 7.0.4 [36]. A rapid boostrap analysis using 1000 replicates with a following search for the best scoring ML tree was conducted in two separate runs using the WAGF+GAMMA+I model. For each run, the final ML optimization was conducted for every $5^{\text {th }}$ bootstrapped tree to search for the best scoring ML tree.

Sequences are deposited in GenBank accession numbers FM958472-FM958475. 


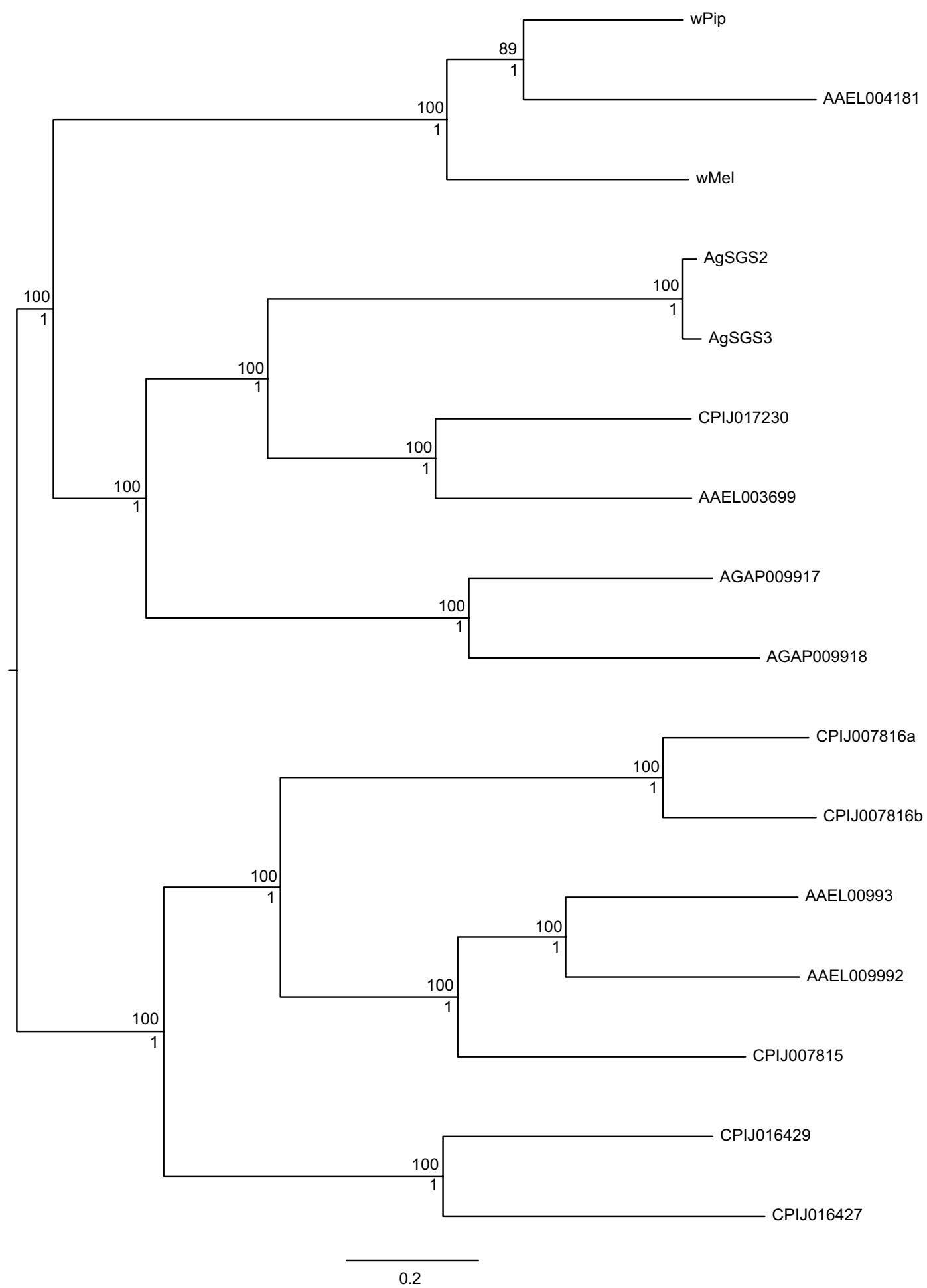

Figure 4

Phylogenetic tree of the SGS genes, AAEL004I8I in Ae. aegypti and homologous sequences in Wolbachia. The fragments of the AAEL004I8I homolog sequenced from Ae. mascarensis are highly similar to AAEL004I8I, and are not shown here. Boostrap values from the ML analysis of 1000 replicates are shown above the branches and posterior probabilities from the Bayesian analysis are shown beneath the branches. 


\section{Authors' contributions}

LK and SPS contributed experimental conception/design, genome analysis and manuscript drafting. Phylogenetic analysis was carried out by LK. ZK and TW performed PCR and RT-PCR experiments. PC and ZK carried out microarray experiments and analyses.

\section{Acknowledgements}

We thank Leonard Munstermann (Yale) for advice on Aedes subgenus Stegomyia; Theresa Howard (Natural History Museum, London) and George McGavin (University Museum, Oxford) for kindly providing preserved Aedes specimens; Charles Godfray (Oxford) and Julian Parkhill (Wellcome Trust Sanger institute) for their helpful comments on the manuscript; and Peter Atkinson (UCR) for permission to use SGS sequences from the Culex quinquefasciatus unpublished genome database. This work was supported by the Wellcome Trust, and the European Union Marie Curie Fellowship to LK.

\section{References}

I. Turelli M, Hoffmann AA: Rapid spread of an inherited incompatibility factor in California Drosophila. Nature 1991, 353:440-442.

2. Taylor MJ, Bandi C, Hoerauf A: Wolbachia bacterial endosymbionts of filarial nematodes. Adv Parasitol 2005, 60:245-284

3. Kondo N, Nikoh N, ljichi N, Shimada M, Fukatsu T: Genome fragment of Wolbachia endosymbiont transferred to $X$ chromosome of host insect. Proceedings of the National Academy of Sciences of the United States of America 2002, 99: I 4280- I 4285.

4. Fenn K, Conlon C, Jones M, Quail MA, Holroyd NE, Parkhill J, Blaxter M: Phylogenetic relationships of the Wolbachia of nematodes and arthropods. PLoS Pathog 2006, 2:e94.

5. Hotopp JC, Clark ME, Oliveira DC, Foster JM, Fischer P, Torres MC, Giebel JD, Kumar N, Ishmael N, Wang S, Ingram J, Nene RV, Shepard J, Tomkins J, Richards S, Spiro DJ, Ghedin E, Slatko BE, Tettelin H, Werren JH: Widespread lateral gene transfer from intracellular bacteria to multicellular eukaryotes. Science 2007, 3 I7(5845): $1753-1756$.

6. Nikoh N, Tanaka K, Shibata F, Kondo N, Hizume M, Shimada M, Fukatsu T: Wolbachia genome integrated in an insect chromosome: evolution and fate of laterally transferred endosymbiont genes. Genome research 2008, 18:272-280.

7. Bordenstein SR: Evolutionary genomics: transdomain gene transfers. Curr Biol 2007, I7:R935-936.

8. Blaxter M: Symbiont genes in host genomes: fragments with a future? Cell host \& microbe 2007, 2:21 I-2I3.

9. Richly E, Leister D: NUMTs in sequenced eukaryotic genomes. Molecular biology and evolution 2004, 2 I: 1081-1084.

10. Werren JH, Zhang W, Guo LR: Evolution and phylogeny of Wolbachia: reproductive parasites of arthropods. Proceedings 1995, 261:55-63.

II. Reuter M, Pedersen JS, Keller L: Loss of Wolbachia infection during colonisation in the invasive Argentine ant Linepithema humile. Heredity 2005, 94:364-369.

12. Sinkins SP, Godfray HC: Use of Wolbachia to drive nuclear transgenes through insect populations. Proceedings 2004, $271: 1421-1426$

13. Xi Z, Khoo CC, Dobson SL: Wolbachia establishment and invasion in an Aedes aegypti laboratory population. Science 2005, 3 I 0(5746):326-328.

14. Nene V, Wortman JR, Lawson D, Haas B, Kodira C, Tu ZJ, Loftus B, Xi Z, Megy K, Grabherr M, Ren Q, Zdobnov EM, Lobo NF, Campbell KS, Brown SE, Bonaldo MF, Zhu J, Sinkins SP, Hogenkamp DG, Amedeo P, Arensburger P, Atkinson PW, Bidwell S, Biedler J, Birney E, Bruggner RV, Costas J, Coy MR, Crabtree J, Crawford M, Debruyn B, Decaprio D, Eiglmeier K, Eisenstadt E, El-Dorry H, Gelbart WM, Gomes SL, Hammond M, Hannick LI, Hogan JR, Holmes MH, Jaffe D, Johnston JS, Kennedy RC, Koo H, Kravitz S, Kriventseva EV, Kulp D, Labutti K, Lee E, Li S, Lovin DD, Mao C, Mauceli E, Menck CF, Miller JR, Montgomery P, Mori A, Nascimento AL, Naveira HF, Nusbaum C, O'Leary S, Orvis J, Pertea M, Quesneville H, Reidenbach KR, Rogers YH, Roth CW, Schneider JR, Schatz M, Shumway M, Stanke M, Stinson
EO, Tubio JM, Vanzee JP, Veriovski-Almeida S, Werner D, White O, Wyder S, Zeng Q, Zhao Q, Zhao Y, Hill CA, Raikhel AS, Soares MB, Knudson DL, Lee NH, Galagan J, Salzberg SL, Paulsen IT, Dimopoulos G, Collins FH, Birren B, Fraser-Liggett CM, Severson DW: Genome sequence of Aedes aegypti, a major arbovirus vector. Science 2007, 3 I 6(5832): 1718-1723.

15. Klasson L, Walker T, Sebaihia M, Sanders MJ, Quail MA, Lord A, Sanders S, Earl J, O'Neill SL, Thomson N, Sinkins SP, Parkhill J: Genome Evolution of Wolbachia Strain wPip from the Culex pipiens Group. Mol Biol Evol 2008, 25(9): $1877-1887$.

16. Wu M, Sun LV, Vamathevan J, Riegler M, Deboy R, Brownlie JC, McGraw EA, Martin W, Esser C, Ahmadinejad N, Wiegand C, Madupu R, Beanan MJ, Brinkac LM, Daugherty SC, Durkin AS, Kolonay JF, Nelson WC, Mohamoud Y, Lee P, Berry K, Young MB, Utterback T, Weidman J, Nierman WC, Paulsen IT, Nelson KE, Tettelin H, O'Neill SL, Eisen JA: Phylogenomics of the reproductive parasite Wolbachia pipientis wMel: a streamlined genome overrun by mobile genetic elements. PLoS biology 2004, 2:E69.

17. Holt RA, Subramanian GM, Halpern A, Sutton GG, Charlab R, Nusskern DR, Wincker P, Clark AG, Ribeiro JM, Wides R, Salzberg SL, Loftus B, Yandell M, Majoros WH, Rusch DB, Lai Z, Kraft CL, Abril JF, Anthouard V, Arensburger P, Atkinson PW, Baden H, de Berardinis V, Baldwin D, Benes V, Biedler J, Blass C, Bolanos R, Boscus D, Barnstead M, Cai S, Center A, Chaturverdi K, Christophides GK, Chrystal MA, Clamp M, Cravchik A, Curwen V, Dana A, Delcher A, Dew I, Evans CA, Flanigan M, Grundschober-Freimoser A, Friedli L, Gu Z, Guan P, Guigo R, Hillenmeyer ME, Hladun SL, Hogan JR, Hong YS, Hoover J, Jaillon O, Ke Z, Kodira C, Kokoza E, Koutsos A, Letunic I, Levitsky A, Liang Y, Lin JJ, Lobo NF, Lopez JR, Malek JA, McIntosh TC, Meister S, Miller J, Mobarry C, Mongin E, Murphy SD, O'Brochta DA, Pfannkoch C, Qi R, Regier MA, Remington K, Shao H, Sharakhova MV, Sitter CD, Shetty J, Smith TJ, Strong R, Sun J, Thomasova D, Ton LQ, Topalis P, Tu Z, Unger MF, Walenz B, Wang A, Wang J, Wang M, Wang X, Woodford KJ, Wortman JR, Wu M, Yao A, Zdobnov EM, Zhang H, Zhao Q, Zhao S, Zhu SC, Zhimulev I, Coluzzi M, della Torre A, Roth CW, Louis C, Kalush F, Mural RJ, Myers EW, Adams MD, Smith HO, Broder S, Gardner MJ, Fraser CM, Birney E, Bork P, Brey PT, Venter JC, Weissenbach J, Kafatos FC, Collins FH, Hoffman SL: The genome sequence of the malaria mosquito Anopheles gambiae. Science 2002, 298(559I): I29-I49.

18. Hilburn LR, Rai KS: Genetic analysis of abnormal male sexual development in Aedes aegypti and Ae. mascarensis backcross progeny. The Journal of heredity 1982, 73:59-63.

19. Masui S, Kamoda S, Sasaki T, Ishikawa H: Distribution and evolution of bacteriophage WO in Wolbachia, the endosymbiont causing sexual alterations in arthropods. Journal of molecular evolution 2000, 5 I:49I-497.

20. Masui S, Kuroiwa H, Sasaki T, Inui M, Kuroiwa T, Ishikawa H: Bacteriophage WO and virus-like particles in Wolbachia, an endosymbiont of arthropods. Biochem Biophys Res Commun 200I, 283: 1099-II04.

2I. Wright JD, Sjostrand FS, Portaro JK, Barr AR: The ultrastructure of the rickettsia-like microorganism Wolbachia pipientis and associated virus-like bodies in the mosquito Culex pipiens. $J$ Ultrastruct Res 1978, 63:79-85.

22. Sinkins SP, Walker T, Lynd AR, Steven AR, Makepeace BL, Godfray $\mathrm{HC}$, Parkhill J: Wolbachia variability and host effects on crossing type in Culex mosquitoes. Nature 2005, 436:257-260.

23. Sanogo YO, Dobson SL: Molecular discrimination of Wolbachia in the Culex pipiens complex: evidence for variable bacteriophage hyperparasitism. Insect Mol Biol 2004, I 3:365-369.

24. Bordenstein SR, Wernegreen JJ: Bacteriophage flux in endosymbionts (Wolbachia): infection frequency, lateral transfer, and recombination rates. Molecular biology and evolution 2004, 21:198|-|99|.

25. Iturbe-Ormaetxe I, Burke GR, Riegler M, O'Neill SL: Distribution, expression, and motif variability of ankyrin domain genes in Wolbachia pipientis. Journal of bacteriology 2005, I87:5।36-5। 45 .

26. Arca B, Lombardo F, Valenzuela JG, Francischetti IM, Marinotti O, Coluzzi M, Ribeiro JM: An updated catalogue of salivary gland transcripts in the adult female mosquito, Anopheles gambiae. The Journal of experimental biology 2005, 208:397|-3986.

27. Korochkina S, Barreau C, Pradel G, Jeffery E, Li J, Natarajan R, Shabanowitz J, Hunt D, Frevert U, Vernick KD: A mosquito-specific protein family includes candidate receptors for malaria spo- 
rozoite invasion of salivary glands. Cellular microbiology 2006, 8:163-175.

28. Walker T, Klasson L, Sebaihia M, Sanders MJ, Thomson NR, Parkhill J, Sinkins SP: Ankyrin repeat domain-encoding genes in the wPip strain of Wolbachia from the Culex pipiens group. $B M C$ Biol 2007, 5:39.

29. Rozen S, Skaletsky H: Primer3 on the WWW for general users and for biologist programmers. Methods Mol Biol 2000, 132:365-386.

30. Zhou W, Rousset F, O'Neil S: Phylogeny and PCR-based classification of Wolbachia strains using wsp gene sequences. Proceedings 1998, 265:509-5I5.

31. Dutton TJ, Sinkins SP: Strain-specific quantification of Wolbachia density in Aedes albopictus and effects of larval rearing conditions. Insect Mol Biol 2004, 13:317-322.

32. Agilent Technologies eArray [https://earray.chem.agilent.com/ earray]

33. VectorBase [http://www.vectorbase.org]

34. Edgar RC: MUSCLE: multiple sequence alignment with high accuracy and high throughput. Nucleic acids research 2004, 32:1792-1797.

35. Huelsenbeck JP, Ronquist F: MRBAYES: Bayesian inference of phylogenetic trees. Bioinformatics (Oxford, England) 200I, 17:754-755.

36. Stamatakis A: RAxML-VI-HPC: maximum likelihood-based phylogenetic analyses with thousands of taxa and mixed models. Bioinformatics (Oxford, England) 2006, 22:2688-2690.

Publish with Bio Med Central and every scientist can read your work free of charge

"BioMed Central will be the most significant development for disseminating the results of biomedical research in our lifetime. "

Sir Paul Nurse, Cancer Research UK

Your research papers will be:

- available free of charge to the entire biomedical community

- peer reviewed and published immediately upon acceptance

- cited in PubMed and archived on PubMed Central

- yours - you keep the copyright

Submit your manuscript here:

http://www.biomedcentral.com/info/publishing_adv.asp
BiolMedcentral 